\title{
Incorporation of children of immigrants: the case of descendants of immigrants from Turkey in Sweden
}

\author{
Alireza Behtoui
}

\section{Linköping University Post Print}

\section{Tweet}

N.B.: When citing this work, cite the original article.

This is an electronic version of an article published in:

Alireza Behtoui , Incorporation of children of immigrants: the case of descendants of immigrants from Turkey in Sweden, 2013, Ethnic and Racial Studies, (36), 12, 2141-2159.

Ethnic and Racial Studies is available online at informaworldTM:

http://dx.doi.org/10.1080/01419870.2012.696667

Copyright: Taylor \& Francis (Routledge): SSH Titles http://www.routledge.com/

Postprint available at: Linköping University Electronic Press http://urn.kb.se/resolve?urn=urn:nbn:se:liu:diva-102777 


\title{
Incorporation of children of immigrants
}

\section{The case of descendants of immigrants from Turkey in Sweden}

\author{
Alireza Behtoui
}

\begin{abstract}
This paper investigates incorporation of the children immigrants from Turkey in Sweden through an examination of the educational achievements and labour market outcomes of this group in comparison with the performance of the offspring of nativeborn parents. The aim of the study is to explore whether we can observe a tendency towards 'downward mobility' among young people of immigrant background in Sweden and thereby provide reflections on the existing formulation of the 'segmented assimilation' theory. Findings show that descendants of immigrants seem not to be in the process of downward assimilation, i.e. social exclusion and therefore formation of a distinct 'underclass' in Sweden. The concept of 'subordinate inclusion' is a more appropriate description of the experiences of children of immigrants.
\end{abstract}

Keywords: children of immigrants, segmented assimilation, education, labour market

Forthcoming: Ethnic and Racial Studies 


\section{Introduction}

Studying the fate of immigrants and their descendants in North America and North-West European countries has attracted much scholarly attention during recent decades.

Some scholars argue that immigrants from non-western countries and their children have great difficulty integrating into Western countries, due to wide cultural differences and low educational levels and poor job skills [(See for exampleBorjas 1999) (for a Swedish variant see Scott 1999)]. Such a discourse is prevalent in media reports. Empirical results in North American and West European studies in this field however do not confirm these theories and show that, despite different trajectories, the crucial majority of descendants of immigrants from non-western countries are well integrated in their new country of residence [see for example (Alba and Nee 2003; Portes and Rumbaut 2001), , (Crul and Schneider 2010)].

In a more optimistic scenario, other scholars suggest that, like earlier waves, the post- Second World War immigrants and their children successfully enter the mainstream of Western societies by 'assimilating' the common values, practices and language of their new countries (Alba and Nee 1997). These theories emphasize that the outcomes of assimilation of children of new immigrants are heterogenic. They end up being incorporated either into the middle or working classes in the new environment. This process has on the whole the same outcome as that for the descendants of earlier Europeans immigrants (from Ireland, Italy, Poland and Jewish immigrants from Eastern Europe) who immigrated to the United States during the nineteenth and early twentieth centuries. The challenges confronting immigrants and their descendants today, according to this perspective, are not radically different from earlier cohorts (Waldinger and Perlmann 1998). 
Segmented assimilation (Portes and Zhou 1993) challenges the 'traditional assimilation theory' by asserting that: 'the process [of integration of newcomers] is neither as simple nor as inevitable' (Portes and Rumbaut 2001:45). According to segmented assimilation theory, the majority of children of immigrants achieve either middle class or working class status, but there are still others who are at risk of joining " those at the bottom of society, a new rainbow underclass" (Portes and Rumbaut 2001, p. 45) [1]. This path, which is labelled by Portes et al (2005) as 'downward assimilation', is more likely for those whose stigmatized immigrant background is a 'mark of subordination'. Indicators of this path are, among other things, leaving school early, long term unemployment, poverty, criminality and imprisonment. Such an alternative is more probable today than before, because of the harsher climate for immigrants from non-Western countries ('nonwhites'), the reduction of opportunities for immigrants and their children to find a job due to the restructuring of the labour market, and finally the successive weaknesses of welfare institutions, which has created a large 'underclass'. Difficulties in finding a way to become incorporated into mainstream societies push the children of immigrants towards the formation of an 'oppositional culture' (Zhou 1997). Accordingly, doing well at school is perceived as 'acting white' and as a sign of "being disloyal to one's group" (Portes and Rumbaut 2001, p. 60).

The segmented assimilation theory, developed mainly by American scholars, has also been employed by some researchers to investigate the integration of the children of immigrants in Western European countries (Vermeulen 2010),(Silberman, Alba, and Fournier 2007). The main focus in these studies has been on "the theory's two alternative 'modes of incorporation': downward assimilation, and upward mobility" (Thomson and Crul 2007, p. 1032). More precisely, the main question in the 
European context has not been how some children of immigrants are assimilated into the 'underclass', but whether the process happens at all (Vermeulen 2010, p. 1218).

On the other hand, Wacquant (2008) has stated that social marginality of immigrants and their children in the old immigration countries of north-western Europe differs radically form the 'underclass' ghettos of the US, and therefore this notion is not straightforwardly applicable to the European context. This distinction is first and foremost a consequence of the traditionally small and weakening welfare state of US society in comparison to the more developed welfare states of the European countries. As Schierup et al. (2006) mention, inhabitants of the disadvantaged neighbourhoods in European big cities, with a large proportion of people with immigrant backgrounds, despite all difficulties, are included into the social security services like education, health care and labour market programs, which is not the case for the isolated inhabitants 'hyperghettos' in the US.

The Swedish case presents even a different migration policy compared with other European countries. In contrast to central and southern Europe, immigrants in Sweden historically have not been treated as 'guest workers'. The migration policy is characterized by the expectation that immigrants would become citizens someday. More than 75 per cent of them are Swedish citizens (Schierup, Hansen, and Castles 2006, p. 195) [2]. Furthermore the Swedish welfare regime has often been considered the most highly developed one of its kind and has generally been successful in handling poverty, at least until the beginning of 1990:s (Esping-Andersen 1996). Immigrants have, at the same time, enjoyed full access to the Swedish welfare system (Scheirup et al. 2006).

Extending the study of the incorporation of children of immigrants beyond the U.S. helps to develop 'segmented assimilation' theory. This paper examines the 
experiences of the "descendants of immigrants from Turkey" (DIT) in Sweden through an investigation of the educational achievements and labour market outcomes of this group compared with children of natives. The aim of the study is to explore whether we can observe a tendency toward downward mobility among the DIT and thereby provide reflections on the existing formulation of the segmented assimilation theory.

The following research questions are posed:

1. What are the educational achievements and labour market outcomes of the DIT compared with children of natives?

2. Can different kinds of career paths between children of natives and the DIT group in the Swedish context be detected?

3. Is it possible to identify whether some of the DIT constitute a group at risk of 'downward' assimilation?

The reminder of this paper is organized as follows: the next section is about the Swedish context, section 3 contains a description of the data, section 4 introduces results and section 5 concludes the paper.

\section{The Swedish context and descendants immigrants from Turkey}

The pattern of immigration to Sweden after the Second World War shares similarities with that in other north-western European countries. The first groups of immigrant workers came from Finland, followed by workers from Mediterranean Europe (Italy, Greece) as well as the wider European periphery (Yugoslavia, Turkey), and then during the 1970s and 1980s refugees mainly came from the 'Third World' and Eastern Europe (Scheirup et al. 2006). Sweden has now one of the largest proportions of 
immigrants to total population among OECD countries. According to Swedish statistics, immigrants and those born to two immigrant parents approached 1.7 million or about 18.5 per cent of a total Swedish population of 9.3 million in 2009 .

Following the Second World War, immigrants were successful in finding jobs, but in subordinate positions. From the 1980s, while still pushed to subordinate positions, immigrants have also experienced higher unemployment and a lower occupational rate (Neergaard 2006).

The first groups of immigrants from Turkey began arriving in Sweden in the mid-1960s. They were recruited by the Swedish Employment Agency. Lonely immigrant men of this period brought their wives and children to Sweden during the second phase in the 1970s (family reunification). The third phase of migration from Turkey was at the end of 1970s and into the 1980s with the arrival of political refugees after the military coup d'etat in 1980 . They came, together with members of Kurdish or Syriani-Assyrian minority groups, as a consequence of the political and social crisis [3].

The case of the DIT group in Sweden is interesting. Like the offspring of Mexican immigrants in the United States (Lpoez and Stanton-Salazar 2001), numerous parents of this group had had only a few years of schooling and brought limited urban cultural skills. Furthermore, they are assumed to be 'Muslims' who according to Vermeulen (2010, p. 1220) "are at the bottom of the 'ethno-racial' hierarchy' in Europe". Large numbers of the offspring of immigrants from Turkey (born in the 1970s and 1980s) have now reached adulthood and are entering the labour market.

\section{Data}


This study draws its empirical base from two sources. First from the LISA database (Longitudinal integration database for health insurance and labor market studies), a registered database administrated by Statistic Sweden, and then the Swedish TIES-survey data, a part of the international research project "Integration of Second Generation Europeans" (TIES). (For more information about the TIESsurvey, see Crul and Schneider 2010).

From the LISA database, all Swedish-born inhabitants in Stockholm County [4] who had two parents from Turkey and who were 18 to 36 years old in 2008 are selected. This group are compared with a randomly selected reference group consisting of 20 percent of all young people of the same age groups from Stockholm who had two native parents. The LISA database contains highly reliable information about the entire population of Sweden and consequently descriptive data and all estimates in this study (and reported in tables) are entirely based on this source.

The Swedish TIES-survey data consist of a sample of children of immigrants from Turkey, of the same age groups as the LISA sample, living in Stockholm County at the time of the survey. They were interviewed in 2008 and compared with a similar group of young people with native parents. Despite the fact that the response rate in the TIES survey is low (in all 43\%), TIES data are still valuable as a complementary source of information. By using face-to-face interviews (which lasted about one hour each), the survey contains information which is not available in registered data.

\section{Results}

The descriptive statistics, reported in Table 1, indicate that individuals in our reference group are on average two years older than the children of immigrants, which has relevance for the explanation of differences found between social positions of members of various groups. 
The educational level of the children of immigrants from Turkey is generally lower than that of children of natives. This is not unexpected because the parents of DIT are considerably less well educated. Regarding the labour market status of respondents, it can be observed that a large proportion of individuals in both groups are either employed/self-employed or doing something else such as studying, doing military service or taking parental leave. The proportion of children of immigrants form Turkey in the first group is lower than the reference group and higher among the second group (partly because they were younger). A considerable proportion of young people with immigrant background are among those looking for a job or in the nonactive group.

On the whole the descriptive data demonstrate that children of immigrants from Turkey belong to the lower stratum of young people in Sweden (to judge by their education and their labour market status), just as their parents belonged to the lower classes of society.

\section{Table 1 about here}

Given the differences in demographic and socioeconomic background of individuals in these two groups, the impact of various characteristics of respondents on their educational achievements and labour market status should be investigated more rigorously. Details of this appear in the following sections.

\section{Educational achievements}

Previous studies that compared educational achievements of children of immigrants and natives show that members of the former group generally have a lower 
educational level than members of the latter group ('gross' disadvantages). But the differences in educational achievement tend to decrease substantially or even become an advantageous compared with majority pupils if one takes into account the parents' education and social background (For Sweden see Behtoui 2006b; Jonsson and Rudolphi 2010), and the same holds for children of immigrants in the Netherlands (Werfhorst and Tubergen 2007), and Germany (Kristen and Dollmann 2010)].

Educational attainments of the respondents, measured in years of education are used as outcomes for estimating in linear probability models in this section. Since information about the educational level of individuals in our dataset is quite detailed (11 levels) it is possible to measure educational attainments quantitatively in years. In different models (presented below in Table 2), the impacts of several characteristics of young people on their educational achievements are investigated.

The coefficient of Model 1 shows the 'gross' disadvantage of having an immigrant background. In Model 2 gender and age variables are included. Due to the wide range of the age of respondents in this study, we find that the older respondents have more education, which is expected. Compared with women, men are associated with slightly lower educational achievement. The coefficient of immigrant background shrinks with the inclusion of controls for gender and age in Model 2, mostly because respondents from the DIT group are younger than those in the reference group.

In the last Model (3), educational attainments of mothers and fathers are added. As expected, educational capital of parents has a positive and significant impact on the educational achievements of young people (note it is the mothers' educational level which has a greater impact than the fathers'). Furthermore, by including these variables in the estimates, the coefficient of immigrant background is qualitatively 
altered and is no longer statistically significant. In other words, after controlling for age, gender and family background, there is no significant difference in educational achievement between children of natives and immigrants. The same results are confirmed by Ties survey data (not shown here but available upon request). In line with the previous studies, these results demonstrate that the educational achievements of children of immigrants from Turkey are comparable to those of young people with native parents with similar socioeconomic and demographic background.

\section{Table 2 about here}

Given these results, it is worth mentioning the following:

First, the Swedish TIES- survey data provides information about how Swedish schools were segregated when the respondents were in primary and secondary schools. More than 3 out of 4 children of immigrants from Turkey studied in schools where more than 50 per cent the pupils had immigrant backgrounds, while about 3 out of 4 of children from the native reference group attended schools that had almost none with immigrant backgrounds. As previous research shows, segregation of school according to class background and 'ethnicity' has a negative impact on the educational outcomes of disadvantaged social groups (Roscigno, Tomaskovic-Devey, and Crowley. 2006).

Secondly, young people in the reference group (children of natives) assert that about 92 percent of their friends during the secondary school period were of similar backgrounds, while only about 42 percent of the DIT group had friends with native backgrounds (due presumably to school segregation). Given the power position of 'natives' in the hierarchy of the society in general, one can assume that having more 
'natives' in one's network has a positive impact on one's social capital accumulation [5].

Thirdly, parents' support and involvement in the educational process of their children contribute significantly to overcoming the structural disadvantages that segregation brings for children.

The results indicate that compared with 'natives', immigrant parents more often spent time checking their children's homework, talked with them about school and studies and to a higher extend met with or talked to their teachers. This is probably because immigrant parents (in spite of their lower educational levels) have higher expectations about their children's educational achievements (Rumbaut and Portes 2001). Yet, immigrants from Turkey could not give practical help with homework, at the same extent as 'natives', due to their own lower level of education (see Table 1).

Finally, children of immigrants from Turkey (both boys and girls) to a lesser extent, than children of natives, perceived that they had been forced to be involved in household tasks (do household chores or look after siblings). In the case of girls this result is totally against the commonly perceived view of immigrant groups and their expectations of education of girls. Fewer daughters of immigrants from Turkey compared with daughters of natives answered "very often" or "often" regarding their involvement in the household chores while they were studying in secondary school.

Using the Swedish TIES- survey data, we have furthermore estimated the impact of: a) segregated schools, b) having Swedish friends during the secondary school period, and c) parents' support in the educational progress of their children (not shown here but available upon request). The results of these estimates show that, on the whole, segregated schools negatively affect the educational achievements of respondents of the Ties survey, whereas having Swedish friends and parental support 
and involvement have a positive impact on the outcome. The signs of coefficients are the same for both the DIT and the reference group when we run a separate regression for each group.

\section{Labour market outcomes}

Previous studies have demonstrated the labour market disadvantages for young people with immigrant parents from non-western countries compared with others [See for example Portes et al 2005 for U.S., Silberman et al (2007) for France and (Crul and Heering 2008) for Netherlands]. Swedish studies in this field confirm these results and demonstrate that the disadvantage for this group of young people cannot entirely be explained by either differences in educational achievements or by the command of the Swedish language [see for example (Behtoui 2006a), (Hammarstedt and Mårten 2006), Nekby et al. (2008)].

Descriptive data for this study, presented in Table 1, show that compared with the children of natives a larger proportion of the DIT group are in the categories 'Unemployed (looking for a job)'or 'Inactive or unknown status'. To have a more precise understanding of this gap, it is necessary to control for other characteristics which can affect respondents' labour market outcomes.

Regarding 'Unemployed (looking for a job)', previous research shows that for many young people the first experiences in the labour market are characterized by part-time work combined with some unemployment spells and studies of various kinds (Henderson 2007). And it is possible that those who were unemployed at the time of the survey could achieve a stable position in the labour market in the future. Nevertheless those who experience long-term unemployment are those who are most likely to become inactive and members of 'the at risk group', and thus more likely to 
risk become marginalised. In the TIES data we can distinguish between those who were unemployed in 2008 and those who had experienced long-term unemployment (more than six months) since they left school. Members of the latter group in this sample are mainly older people who would have entered the labour market in the years of economic crisis in Sweden at the beginning of the 1990s. All of these individuals had a job at the time of the survey.

\section{A. Being at risk of becoming marginalized}

Previous studies also show that those who run a higher risk of becoming marginalised are young people who left school at an early age, without qualifications or experience in the labour market (See for exampleRussell and O'Connell 2001). Among those in the group 'Inactive or unknown status' there are about 55 percent who have only primary school or a lower level of education. Consequently, they can be considered as the 'at risk group'. A total of 738 individuals or about 4 percent of our population are in this group. Of the children of natives, 360 individuals or 3.2 percent fall into the 'Inactive or unknown status' category, compared with 378 individuals or 5.8 percent of young people with immigrant background. It is worth to note that according to previous longitudinal Swedish studies, about 80 percent of individuals in this category have a job or studying when one investigate their labour market position after 5 years (SOU 2003). Consequently, being 'inactive' in a cross sectional study, does not mean that these individual are actually inactive in long term.

A logistic regression is run to estimate the probability of being a member of the 'Inactive' group.

\section{Table 3 about here}


Results presented in Model 1 in Table 3 show that, as with descriptive data, immigrants' background (compared with the reference group) is associated with higher probability of getting into the 'inactive' group, i.e. being member of the DIT group increases the odds of being in this group by 88 percent. But this 'gross gap' may possibly be the consequence of the belonging of the DIT group members to lower stratum of social hierarchy. To compare these two groups in a right way, we should further control for other characteristics.

The 'gross gap' decreases significantly with the inclusion of age and educational level of respondents in estimates for Model 2. Compared to the reference group, the odds of being among 'inactive group' decrease from 88 to 28 percent for DIT group. Other results in Model 2 are more expected. Having secondary school education or a university degree decreases the odds of being in this group by 72 and 90 percent respectively. But each additional year of age increases the odds by 5 percent.

As a proxy for the socioeconomic background of individuals in the dataset, the labour market position of parents (if the father or mother has a job or not) are included in Model 3. By adding these variables, the coefficient of the immigrant background in the Model 3 is no longer statistically significant, which means that, after controlling for age, education and socioeconomic background of the individuals, there is no difference between members of the reference group and the DIT group with regard to the risk of ending up in the 'Inactive' group.

\section{Having a job that corresponds to one's skills}


Answering the question in the TIES survey "does your job correspond well with your level of education and/or your skills?", children of immigrants from Turkey state more often than those in the reference group that they are over-qualified for their current job. To scrutinise this assertion more closely, the salary of those who according to the LISA dataset have a job are examined. We use a linear regression to investigate the effect of various characteristics of individuals on their incomes from work. The results presented below in Table 4 .

\section{Table 4 about here}

In Model 1 the gross wage gap of children of immigrants from Turkey relative to the reference group is shown, and indicates that the salary for the former group is about 69 percent lower. In Model 2 'age' and 'years of education' of individuals (human capital variables) are added. For each additional year of age (hence more labour market experiences) and each additional year of education, salaries increase with 7 and 14 percent respectively. Inclusion of these variables shrinks the wage gap between the two groups to 33 percent.

In Model 3 two other variables, gender and 'have children', have been added. Being men rather than women is associated with 19 percent more salary and having children with 45 percent lower salary. The introduction of these variables reduces the gap even more, to 24 percent. However a significant income gap relative to the reference group persists even after controlling for the above-mentioned human capital and demographical variables.

In Model 4 we add a further variable which indicates 'occupational segregation' of immigrants and their children (leGrand and Szulkin 2002). This dummy variable takes a value of one if individuals are employees in 'Government service', 'large 
private-sector workplaces' and 'other organizations' and zero otherwise. By introducing this new variable, the gap between the salary of young people of native background and immigrant background decreases by about 13 percent. In other words, occupational segregation of descendant of immigrants (where they are able to obtain a job) has a crucial effect on their wages. The results become more interesting when we realize that the wage gap between men and women disappears with the addition of this variable. It means that the same occupational segregation which operates in the case of men and women in the Swedish labour market is at work for individuals with and without an immigrant background. Furthermore the impact of educational achievements decreases in this model, which demonstrates that the return on educational capital is different in different sectors of the Swedish labour market.

\section{B. Explaining the inferior positions in the labour market}

Two possible explanations for the inferior position of children of immigrants in labour market are, as Loury (2002) suggests, discrimination in contract and discrimination in contact. The former denotes the unequal treatment of individuals on the basis of race/ethnicity in the labor market (for example, in recruitment and promotion), and the latter means the unequal treatment of people on the basis of race/ethnicity in the contexts of more informal private spheres of life (for example, friendship or partnership) [6]. Resources which are accessible via social networks have a substantial impact on our position in the labour market (Lin 2001). Hence, discrimination in contact, as Loury (2002, p. 99) suggests, has extremely destructive consequences for stigmatized immigrant groups, because it affects "individual social mobility and intergenerational status transmission". 
The results of the Swedish TIES survey demonstrate an apparent perception of discrimination in contract among descendants of immigrants from Turkey. About 27 percent of them reported that they had personally experienced discrimination frequently, regularly or occasionally. More than 60 per cent of them also stated that stigmatized immigrant groups, (namely 'Muslims', 'people with dark skin' and 'Turks'), are frequently or regularly subject to discrimination in Sweden. The statement is confirmed also by members of the reference group.

Regarding discrimination in contact the TIES survey shows:

a) An overwhelming majority of best friends of the members of young people with native parents were children of natives, both during the secondary school period and at the time of survey. The majority of the best friends of children of immigrants from Turkey, on the other hand, were children of immigrants from non western-countries. At best, only 25 per cent of young people from the DIT group have friends with a native background.

b) About 86 per cent of children of natives have a partner with a native background compared with about 18 percent for children of immigrants from Turkey. On the other hand, about 6 per cent of children of natives have partners with an immigrant background (non-Western countries), while the equivalent figure for children of immigrants from Turkey is about 80 per cent.

As mentioned earlier, given the power position of the 'natives' in the hierarchy of the society in general, one can assume that having more 'natives' in one's network means access to more social capital. If social capital consists, to some extent, of those potential resources that are provided by an individual's parents, relatives, partner, friends and acquaintances (Bourdieu 2001), we can conclude that young people from 
the DIT group in the TIES survey have access to less social capital compared with children of natives. Access to social capital links young people to individuals in their network who, because they possess greater amounts of economic and cultural capital, might help them with advice, further connections, information, loans, and so on. Restricted access to social capital eliminates or limits the opportunities of the children of immigrants both in the educational process and in the labour market.

To examine the impact of different types of discrimination in the labour market on the position of respondents, we used the TIES data. After controlling for immigrant background, age, gender, education and the number of children they have, we have added three new variables. First, if the respondent has suffered discrimination, secondly if the respondent has a partner with a native background, and if he/she has a number of friends who have native parents. Those who reported experiencing discrimination had lower incomes, on the other hand having partners or friends with a native background had a positive effect on their incomes (not shown here, but available on request).

\section{Summary and discussion}

The educational level of the children of immigrants from Turkey is generally lower than that of children of natives. However, once other background variables (such as age, gender and educational level of the parents) are controlled for, there is no more significant difference between two groups regarding educational achievements. In other words, children of immigrants have been able to obtain the same educational achievements as young people from the majority group with the same socioeconomic background. 
Results also indicate that the offspring of immigrants from Turkey have studied in segregated (in terms of class and immigrant background) schools and neighbourhoods. Consequently, they have also experienced a segregated friendship network during their school years. But their parents' ambition, higher expectations and extra exertion have compensated for the negative effects of such segregation.

Given the same education, gender and age, results indicate that young people with immigrant backgrounds (compared with children of natives) in this study run a higher risk of being in the 'Inactive group'. However, after controlling for age, education and class background there in no significant difference between them and those with a native background. On the other hand, the relative number of young people with an immigrant background among the unemployed (who are looking for work) is higher than those with a native background. But this gap does not disappear even after controlling for the human capital and class background of individuals.

Members of the DIT group, to a greater extent than the reference group, considered themselves overqualified for their current job. In line with this, we find that the wage gap between those young people with immigrant and native backgrounds who have a job cannot be explained by human capital and demographic variables. Occupational segregation, on the other hand, seems to explain a part of such a salary gap.

To summarize, despite similar educational attainment, offspring of immigrants from Turkey have not been able to get hold of a position in the labour market on a par with the children of natives. This can indicate unequal treatment of young people with an immigrant background in the Swedish labour market. The stigmatized immigrant's background restricts the opportunities for formal interactions (market relationships 
such as labour market and trade) and informal relationships (such as friendships, membership of informal groups and marriage).

Going back to the third question of this study, based on our result we can conclude that descendants of immigrants from Turkey seems not to be in the process of social exclusion and formation of an 'underclass' in Sweden.

The progress of neoliberalization has not been the same in all Western countries. As Harvey (2005, p. 115) puts it, "Sweden is an example of what might be called 'circumscribed neoliberalization', Dismantling the welfare state, deregulating the labour market, destroying all forms of social solidarity (including trade unions) are not yet as far-reaching in Sweden as in the English-speaking world. Despite the latest negative developments, people (including immigrants and their children) remained broadly attached to its welfare structure. In contrast to the traditionally small American welfare system, the more developed Swedish welfare state and strong presence of public intervention have restrained (even if not wholly prevented) the marginalisation of people at the bottom of the social hierarchy (Wacquant 2008). By and large, thanks to the institutions of a large and relatively robust welfare state, more regulated labour market and powerful trade unions, people situated at the bottom of social hierarchy enjoy a high degree of social security and relative material welfare. This differentiation demonstrates the importance of institutional and ideological setting of every society and how the outcome of the same process (neoliberalization) has been different in different contexts. The findings of this case study also show that incorporation of children of immigrants depends, among other things, on the context of the receiving societies, i.e. different types of national welfare regimes and migration policy. Current theories of incorporation of immigrants and their offspring 
discern following factors as decisive ones in this process: a) the individual, family and community resources that they have access to (economic, cultural and social capital) and, b) the social environment that receive them, that is the politic of the host government, the attitudes and opinion of civil society and native population toward them. What we can add into the second level (contextual factors) is various alternative paths of incorporation which are available to the offspring of immigrants. To survive in the deprived environment of American 'hypergetto', young people settled in close proximity to these areas must adopt the attitudes and norms of the ghetto (Portes and Rumbaut 2001). In contrast to this 'downward assimilation' of some part of offspring of immigrants in the American metropolis, it seems not to be the case for children of immigrants from Turkey in Sweden to form a distinct 'immigrant underclass', because of the absence of such an alternative in the Swedish society up till now. Inequalities have certainly increased in Sweden during the last few years but other problems such as racialized poverty, long-term unemployment, low salaried jobs, and criminality are still much more limited in Sweden than in US or several other EU member states. Nevertheless, "the current situation is exceedingly ambiguous" (Shierup et al. 2006, p. 229).

When this is said, however, we should not disregard the reality of the stigmatization and discrimination of children of immigrants in Swedish schools and the labour market. Unequal treatments hamper their social mobility. It is more difficult for them (compared with young people with native parents) to achieve a social status appropriate to their skills and merits. To have the same level of education as natives and being incorporated into the labour market does not mean that the offspring of immigrants from Turkey are accepted and treated as socially equal. The notion of 'subordinate inclusion' describes more appropriately the specificities of 
incorporation of immigrants and their children in Sweden. 'Subordinate inclusion' describes situation in which stigmatized immigrant groups are included into the institutional system in general, but placed in subordinate positions in all spheres of life, from education to the labour market and from marriage market to friendship and neighbourhood (Mulinari 2008).

Certain limitations restrict the generality of our findings. First of all, our analysis includes only young people who are native-born of foreign parentage (the so called 'second generation'). The literature in this field shows that young people who are born abroad and immigrate at an early age ('the in-between or 1.5 generation') tend to be more at-risk (Thomson \& Crul 2007, p. 1033). Secondly, this case study includes only the descendants of immigrants from Turkey during 1960s-1980s. To have a more comprehensive account of incorporation of children of immigrants in Sweden, we should further study the outcomes of other immigrants groups which came later and have been target of much more widespread prejudice for example descendant of immigrants from Somalia who arrived in the beginning of 1990s [7]. Another important limitation in our cross-sectional data is that it is not possible to follow the young people in this study for a long period. More longitudinal research is needed to see how the process of integration in Sweden evolves with time. 


\section{Notes}

1. According to Stepick and Stepick (2010: 1150) "the concept of segmented assimilation could apply to the children of immigrants in any country, but it was developed specifically in reference to the US children of immigrants who arrived after 1965".

2. According to data for this study about 98 percent of children of immigrants from Turkey have been Swedish citizens year 2008. Almost 92 of their mothers and 84 percent of their fathers are as well Swedish citizens.

3. The case of immigrants from Turkey at once demonstrates that national origin cannot be always a good proxy for mode of integration. Immigrants from Turkey, just like many other immigrant groups, in spite of the same national origin do not inevitably belong to the same 'ethnic' communities in new country of residence (Sweden) and have formed diverse communities and are divided between many different communities (Kurdish, SyrianiAssyrian, Armenian and Turkish). In other words, the same 'ethnic' label can denote different contents in different places.

4. Stockholm is harbouring the largest communities of immigrants from Turkey in Sweden. Almost 60 percent of the DIT group in Sweden are living in Stockholm, according to LISA.

5. The definition of social capital here is close to Bourdieu's definition (2001), which underlines that in our hierarchically-ordered society some individuals are connected to resource-rich networks, while others, due to the tribal stigma of race/ethnicity or their lower socioeconomic positions, have no such connections. See further in the paper, Loury's notion of "discrimination in contact" (the unequal treatment of persons on the basis of race/ethnicity in the more informal private spheres of life such as friendship and partnership) as explanation for why racially/ethnically stigmatised groups have less access to social capital.

6. Concerning the binary contrast between formal and informal, Jenkins (1994:210) stresses that there is no clear-cut distinction between formal and informal interactions; rather there is a continuum of emphasis: "the formal is simultaneously an absence and a presence within the informal and vice versa". 
7. Individuals born in Sweden with parents from Somalia have not yet reached adulthood to enter in the labour market. 


\begin{tabular}{lll}
\hline & Reference group & $\begin{array}{l}\text { Children of Immigrants } \\
\text { from Turkey }\end{array}$ \\
\hline Gender (female \%) & 50 & 49 \\
Have children (\%) & 49 & 74 \\
Age (mean year) & 27 & 25 \\
Highest educational level (\%) & & \\
Primary school & 15 & 35 \\
Secondary school & 49 & 51 \\
Post-Secondary & 35 & 13 \\
Mean Education years & 12.7 & 11.4 \\
Fathers' Education (mean year) & 12.4 & 9.3 \\
Mothers' Education (mean year) & 12.5 & 8.7 \\
Father has a job (\%) & 76 & 61 \\
Father has a job (\%) & 83 & 46 \\
Labour market status respondents (\%) & & \\
Have a job & 85.8 & 70.7 \\
Studying, military service or parental leave & 5.7 & 11.4 \\
Unemployed (looking for work) & 5.3 & 12.1 \\
Inactive or Unknown status & 3.2 & 5.8 \\
Recipient of social security (among all) & 2.2 & 4.7 \\
\hline N & & \\
\hline
\end{tabular}

Data source: LISA database 
Table 2. Years of education, OLS regression, unstandardized coefficients (Standard Errors in Parentheses), $\mathrm{N}=17807$

\begin{tabular}{|c|c|c|c|}
\hline & Model 1 & Model 2 & Model 3 \\
\hline \multicolumn{4}{|c|}{ 'Ethnicity' (children of natives ref.) } \\
\hline \multirow[t]{2}{*}{ Immigrants' Background } & $-1.4^{\star * *}$ & $-1^{* * *}$ & -.03 \\
\hline & $(.033)$ & $(.031)$ & $(.04)$ \\
\hline \multirow{2}{*}{ Gender (male) } & & $-.52^{\star * \star}$ & $-.53^{\star \star \star}$ \\
\hline & & $(.03)$ & $(.03)$ \\
\hline \multirow{2}{*}{ Age } & & $.16^{\star * *}$ & $.17^{\star \star *}$ \\
\hline & & $(.002)$ & $(.002)$ \\
\hline \multirow[t]{2}{*}{ Mother's education } & & & $.14^{\star \star *}$ \\
\hline & & & $(.007)$ \\
\hline \multirow[t]{2}{*}{ Father's education } & & & $.12^{\star \star *}$ \\
\hline & & & $(.006)$ \\
\hline $\mathrm{R}^{2}$ adj. & .09 & .22 & .30 \\
\hline
\end{tabular}

*** denotes significance at $1 \%$ level, Data source: LISA database 
Table 3. Percent change in odds of being member of 'Inactive or unknown status' group (standard errors in parentheses), $\mathrm{N}=17807$

\begin{tabular}{llll}
\hline & Model 1 & Model 2 & Model 3 \\
\hline 'Ethnicity' (children of natives ref.) & $\%$ & $\%$ & $\%$ \\
Immigrants' Background & $88^{* * *}$ & $28^{* * *}$ & 10 \\
Educational categories (Compulsory School ref.) & $(.07)$ & $(.07)$ & $(.08)$ \\
Secondary School & & $-72^{* * *}$ & $-71^{\star * *}$ \\
& & $(.08)$ & $(.08)$ \\
University & & $-90^{\star * *}$ & $-89^{* * *}$ \\
Age & & $(.14)$ & $(.14)$ \\
Fathers have a job & & $5^{\star * *}$ & $4^{* * *}$ \\
& & $(.007)$ & $(.007)$ \\
Mothers have a job & & & $-23^{\star * *}$ \\
Log likelihood & & & $(.08)$ \\
\hline
\end{tabular}

*** denotes significance at $1 \%$ level, Data source: LISA database 
Table 4. Determinants of LN salary for those who have a job, OLS regression, unstandardized (b) and standardized (Beta) coefficients, $\mathrm{N}=14297$

\begin{tabular}{|c|c|c|c|c|}
\hline & Model 1 & Model 2 & Model 3 & Model 4 \\
\hline \multicolumn{5}{|l|}{ 'Ethnicity' (children of natives ref.) } \\
\hline \multirow[t]{2}{*}{ Immigrants' Background } & $-.69^{\star * \star}$ & $-.33^{\star * \star}$ & $-.24^{\star * *}$ & $-.11^{* * *}$ \\
\hline & $(.03)$ & $(.031)$ & $(.04)$ & $(.03)$ \\
\hline \multirow{2}{*}{ Age } & & $.07^{* \star *}$ & $.07^{* * *}$ & $.05^{\star * *}$ \\
\hline & & $(.003)$ & $(.003)$ & $(.002)$ \\
\hline \multirow{2}{*}{ Education (years) } & & $.14^{\star \star *}$ & $.13^{\star \star *}$ & $.11^{\star \star *}$ \\
\hline & & $(.007)$ & $(.007)$ & $(.006)$ \\
\hline \multirow{2}{*}{ Gender (male) } & & & $.19^{* \star *}$ & .02 \\
\hline & & & $(.03)$ & $(.02)$ \\
\hline \multirow{2}{*}{ Have children } & & & $-.45^{\star \star \star}$ & $-.33^{\star \star \star}$ \\
\hline & & & $(.03)$ & $(.03)$ \\
\hline \multirow{2}{*}{ High salary section of labour market } & & & & $1.7^{* * *}$ \\
\hline & & & & $(.02)$ \\
\hline $\mathrm{R}^{2}$ adj. & .03 & .13 & .15 & .34 \\
\hline
\end{tabular}

*** denotes significance at $1 \%$ level, Data source: LISA database 


\section{References}

Alba, Richard and Victor Nee. 1997. "Rethinking Assimilation Theory for a New Era of Immigration." International Migration Review 31:826-874

Alba, Richard and Victor Nee. 2003. Remaking the American Mainstream: assimilation and contemporary immigration Cambridge, Mass: Harvard University Press.

Behtoui, Alireza. 2006a. Om de hade föräldrar födda på "rätt plats", om ungdomar med utländsk bakgrund i det svenska utbildningssystemet och på den svenska arbetsmarknaden. Norrköping: Integrationsverket.

Behtoui, Alireza. 2006b. Unequal opportunities : the impact of social capital and recruitment methods on immigrants and their children in the Swedish labour market. Linköping: Department of Social and Welfare Studies Linköping University.

Borjas, George J. 1999. Heaven's door : immigration policy and the American economy. Princeton, N.J. ; Oxford: Princeton University Press.

Bourdieu, Pierre. 2001. "The Forms of Capital." Pp. 96-111 in The sociology of economic life. Boulder and Oxford: Westview Press.

Crul, M. and J. Schneider. 2010. "Comparative integration context theory: participation and belonging in new diverse European cities." Ethnic and Racial Studies 33:1249-1268.

Crul, Maurice and Liesbeth Heering. 2008. The position of the Turkish and Moroccan second generation in Amsterdam and Rotterdam Amsterdam Amsterdam University Press.

Esping-Andersen, G. 1996. Welfare States in Transition,. London: SAGE.

Hammarstedt, Mats and Palme Mårten. 2006. "Intergenerational Mobility, Human Capital Transmission and the earnings of Second-Generation Immigrants in Sweden." in IZA. Sweden.

Harvey, David. 2005. A brief history of neoliberalism. Oxford ; New York: Oxford University Press.

Henderson, Sheila 2007. Inventing adulthoods : a biographical approach to youth transitions. London: SAGE Publications.

Jonsson, Jan O. and Frida Rudolphi. 2010. "Weak Performance-Strong Determination: School Achievement and Educational Choice among Children of Immigrants in Sweden." European Sociological Review doi:10.1093/esr/jcq021.:1-22.

Kristen, C. and J. Dollmann. 2010. "Sekundäre Effekte der ethnishen Herkunft: Kinder aus Türkischen Familien am ersten Bildungsübergang." Zeitschrift für Erziehungswissenschaft 12:205-229.

leGrand, C. and R. Szulkin. 2002. "Permanent Disadvantage or Gradual Integration: Explaining the Immigrant-Native Earnings Gap in Sweden." Labour 16:37-64.

Lin, Nan. 2001. Social capital : a theory of social structure and action. Cambridge ; New York: Cambridge University Press.

Loury, Glenn C. 2002. The anatomy of racial inequality. Cambridge, Mass.: Harvard University Press.

Lpoez, David E. and Ricardo D. Stanton-Salazar. 2001. "Mexican Americans: A Second Generation at Risk." Pp. 57-90 in Ethnicities : children of immigrants 
in America, edited by R. n. G. Rumbaut and A. Portes. Berkeley, Calif. ; London: University of California Press.

Mulinari, Diana. 2008. "Women friendly? Understanding gendered racism in Sweden." Pp. 167-182 in The Limits of Political Ambition? Gender Equality and Welfare Politics in Scandinavia, edited by K. Melby, A.-B. Ravn, and C. C. Wetterberg. Bristol: Policy Press.

Neergaard, Anders. 2006. "Rasifierad rekrytering i storstadskommunen: Mellan exkluderad och inkluderad underordning." in Skillnader på kors och tvärs: Arbetsliv, storstad och makt, edited by Gunnarsson, Neergaard, and Nilsson. Stockholm: Normal.

Nekby, Lena, Roger Vilhelmsson, and Gulay Özcan. 2008. "Do Host Country Educations Even Out the Playing Field? Immigrant-Native Labor Market Gaps in Sweden " Journal of Immigrant \& Refugee Studies 6:168 - 196

Portes, Alejandro, Patricia Ferna'ndez-Kelly, and William Haller. 2005. "Segmented assimilation on the ground: The new second generation in early adulthood." Ethnic and Racial Studies 28:1000-1040.

Portes, Alejandro and Rubén G. Rumbaut. 2001. Legacies : the story of the immigrant second generation. Berkeley; London

New York: Univ. of California Press ;

Russell Sage Foundation.

Portes, Alejandro and Min Zhou. 1993. "The new second generation: segmented assimilation and its variants among post-1965 immigrant youth." Annals 530:74-96.

Roscigno, Vincent J., Donald Tomaskovic-Devey, and Martha Crowley. 2006. "Education and the Inequalities of Place." Social Forces 84:2121-45.

Rumbaut, Rubén G. and Alejandro Portes. 2001. Ethnicities : children of immigrants in America. Berkeley, Calif. ; London: University of California Press.

Russell, H. and P.J. O’Connell. 2001. "Getting a job in Europe: The transition from unemployment to work among young people in nine European countries." Work, Employment \& Society 15:1-24.

Schierup, Carl-Ulrik, Peo Hansen, and Stephen Castles. 2006. Migration, Citizenship and the European Welfare State. A European Dilemma. Oxford: Oxford University Press

Scott, Kirk. 1999. The immigrant experience : changing employment and income patterns in Sweden, 1970-1993. Lund: Lund Univ. Press.

Silberman, Roxane, Richard Alba, and Ire`ne Fournier. 2007. "Segmented assimilation in France?" Ethnic and Racial Studies 30:1-27.

SOU. 2003. "Unga utanför." Stockholm: Fritzes offentliga publikationer.

Thomson, M. and M. Crul. 2007. "The Second Generation in Europe and the United States." Journal of Ethnic and Migration Studies 33:1025-1041.

Wacquant, Lo@ c J. D. 2008. Urban outcasts : a comparative sociology of advanced marginality. Cambridge ; Malden, MA: Polity.

Waldinger, Roger and Joel Perlmann. 1998. "Second generations: past, present, future." Journal of Ethnic and Migration Studies 24:5-24.

Werfhorst, Herman G.Van De and Frank Van Tubergen. 2007. "Ethnicity, schooling, and merit in the Netherlands." ETHNICITIES 7:416-444. 
Vermeulen, Hans. 2010. "Segmented assimilation and cross-national comparative research on the integration of immigrants and their children." Ethnic and Racial Studies 33:1214-1230.

Zhou, Min. 1997. "Segmented Assimilation: Issues, Controversies, and Recent Research on the New Second Generation." International Migration Review 31: 975-1008

Alireza Behtoui is Associate Professor in the Department of Social and Welfare Studies (ISV), Institute for Migration, Ethnicity and Society (REMESO) at Linköping University and The Department of Social Anthropology, Stockholm University.

ADDRESS: Linköping University, ISV, SE- 60174 Norrköping, Sweden or Stockholm University, SE-106 91 Stockholm.

E-mail: alireza.behtoui@liu.se 